\title{
Entrepreneurship Education Promotes Individual Entrepreneurial Intention: Does Proactive Personality Work?
}

\author{
Deliang Sun, Hanhui Chen, Peijian Wu, Dong Yang* \\ School of Business Administration, Anhui University of Finance and Economics, Bengbu, China \\ Email: *yangdong@aufe.edu.cn
}

How to cite this paper: Sun, D.L., Chen, H.H., Wu, P.J. and Yang, D. (2020) Entrepreneurship Education Promotes Individual Entrepreneurial Intention: Does Proactive Personality Work? Open Access Library Journal, 7: e6835.

https://doi.org/10.4236/oalib.1106835

Received: September 7, 2020

Accepted: October 27, 2020

Published: October 30, 2020

Copyright $\odot 2020$ by author(s) and Open Access Library Inc.

This work is licensed under the Creative Commons Attribution International License (CC BY 4.0).

http://creativecommons.org/licenses/by/4.0/

\begin{abstract}
The paper takes potential entrepreneurs' personal self-esteem and initiative personality and other trait variables, entrepreneurship education and entrepreneurial attitude as predictors of entrepreneurial intention, collects sample data through questionnaire surveys, and uses SPSS and AMOS software to conduct reliability and validity tests and correlations and regression analysis. The results show that: active personality and entrepreneurial education both positively and significantly affect entrepreneurial intention, while self-esteem and entrepreneurial attitude have no significant impact on the formation of entrepreneurial intention. The conclusions of the research indicate that increasing the intention to start a business can start from two aspects: the promotion of personal initiative and the strengthening of entrepreneurship curriculum education. Finally, suggestions are made for promoting the development of entrepreneurship education in universities.
\end{abstract}

\section{Subject Areas \\ Entrepreneurship}

\section{Keywords}

Proactive Personality, Self-Esteem, Entrepreneurship Education, Entrepreneurial Attitude, Entrepreneurial Intention

\section{Introduction}

In the context of entrepreneurial activities throughout the world, people gradually realize the importance of entrepreneurship. Entrepreneurial activity is regarded as the driving force of economic growth and determines the economic 
prosperity of regions and countries [1]. Entrepreneurial activity is conducive to market innovation and economic growth, as well as to employment and job creation [2]. However, the prerequisite for the effective implementation of entrepreneurial activities is that individuals should have entrepreneurial intention, which is the essential difference between potential and real entrepreneurs [3]. Entrepreneurial intention is a necessary condition for entrepreneurial behaviors [4]. Therefore, it is meaningful to study entrepreneurial intention and its influencing factors.

Scholars at home and abroad have conducted a lot of theoretical exploration and empirical research on entrepreneurial intention. Li Y-Q et al. (2008) found that the factors influencing the entrepreneurial intention of scholars at home and abroad mainly include four aspects: entrepreneur traits, TPB model, entrepreneurial education and entrepreneurial environment [5]. Ji X-Y and Liu A-J (2016) empirically studied the factors that influence college students' entrepreneurial intention through principal component analysis (PCA), which mainly focuses on three aspects: personal internal factors, personal background factors and external environment factors [6]. Obschonka et al. (2017) applied "self-esteem" to the individual trait variable in the study on the entrepreneurial intention of high school students aged 16 - 18 in Finland, and verified that self-esteem not only significantly affects the entrepreneurial intention, but also mediates the relationship between the big five personalities and entrepreneurial intention, which is rare in the research on the influencing factors of entrepreneurial intention in China [7]. Entrepreneurship education has been recognized as one of the factors that affect entrepreneurial intention; this is because the development of entrepreneurial activity cannot leave the entrepreneurship education to the cultivation of potential entrepreneurs; the world's largest open entrepreneurship education in colleges and universities is the purpose of entrepreneurial activity, a professor at the need of knowledge and improving college students' pioneering consciousness and cultivating the ability. However, different studies have found that entrepreneurship education has different effects on entrepreneurship. Obschonka et al. (2017) believe that there is a direct and indirect relationship between entrepreneurs' proactive personality and entrepreneurial alertness, which can help entrepreneurs identify and develop new business opportunities [7]. Botsaris and Vamvaka (2016) conducted an empirical analysis on the relationship between belief, entrepreneurial attitude and entrepreneurial intention, and found that emotional attitude had a more significant influence on entrepreneurial intention than cognitive attitude [8]. Foreign studies on the influence of proactive personality and entrepreneurial attitude on entrepreneurial intention may be included in this study because the influence of factors such as socio-cultural environment and economic environment is different from that in China, so the effect needs to be tested.

The content of this paper is arranged as follows: firstly, the relationship between variables in relevant literature is reviewed and sorted out, and the hypo- 
thesis to be verified is proposed. Then, the research design method of this paper is introduced, including sample selection and collection methods and variable measurement. Secondly, with the help of SPSS and AMOS software, the empirical study was conducted and the research results were analyzed. Finally, the conclusions, shortcomings and prospects of this paper are given.

\section{Literature Review and Hypothesis}

It is generally believed that "entrepreneurial intention" was first proposed by a foreign scholar Bird (1988), and based on the concept of "intention", he defined entrepreneurial intention as directing the entrepreneur's attention, energy and behavior to a specific goal. He believes that entrepreneurial ideas inspired by inspiration must be realized through entrepreneurial intention [9]. After that, many scholars gave their own conceptual definition and research. Domestic representative scholars such as Fan W and Wang C-M (2006) pointed out in their research that entrepreneurial intention is a subjective attitude of potential entrepreneurs on whether to engage in entrepreneurial activities, and the degree to which people have traits similar to entrepreneurs. It is the best entrepreneurial behavior predictor [10]. Based on the above viewpoints, this study believes that entrepreneurial intention is the subjective and objective state of preparation and degree of knowledge, psychology, or behavioral tendencies that potential entrepreneurs take when establishing their own new enterprises.

\subsection{Proactive Personality and Entrepreneurial Intention}

The concept of proactive personality was first proposed by two scholars, Bateman and Crant, in 1993. They defined proactive personality as a personality trait, which was defined as a relatively stable tendency to influence environmental changes [11]. Subsequently, many scholars conducted relevant studies, such as Crant (1996 [12], 2000 [13]), Paul and Shrivastava (2016) [14], which showed that proactive personality could be used as a predictive variable to predict entrepreneurial intention. Domestic scholars Jane D-D et al. (2018) regarded proactive personality as one of the dimensions of personality trait variables [15]. Through empirical research, Chen M-J (2009) found that proactive personality had a significant positive predictive effect on entrepreneurial intention, which indirectly affected individuals' entrepreneurial intention [16]. Accordingly, the following hypothesis is proposed:

$\mathrm{H1}$ : proactive personality significantly positively affects entrepreneurial intention.

\subsection{Self-Esteem and Entrepreneurial Intention}

Ismail et al. (2013) showed that if individuals have a high self-esteem, their intention to start a business will increase [17]. Ayalew and Zeleke (2018), self-esteem and adventure commitment is considered to be the risk factors affecting entrepreneurial intention, one of the qualities of a successful entrepreneur is the prom- 
ise of confidence and risk-taking, a confident students should have the ability to overcome business problems and succeed in business, their research has proved that self-confidence of students have the ability to overcome the business and to carry out business activities successfully, the students' self-esteem in 5\% significance level and self-employment intention positively correlated relationship [18]. Based on the fact that few domestic scholars have studied the influence of self-esteem on entrepreneurial intention, this paper proposes the following hypothesis:

H2: self-esteem has a significantly positive impact on entrepreneurial intention.

\subsection{Entrepreneurship Education and Entrepreneurial Intention}

Entrepreneurship education can cultivate and improve individual entrepreneurship inspiration, entrepreneurship awareness, entrepreneurship knowledge and skills, which in turn will affect the individual's intention to start a business. For example, Walter et al. (2013) conducted an empirical study on how the characteristics of university departments influence college students' independent career choice through four factors including entrepreneurship education and entrepreneurship support plan, and found that the specific effects and functions of entrepreneurship education are difficult to determine [19]. Oosterbeek et al. (2010) pointed out that entrepreneurial education has a negative or even negative effect on the generation of entrepreneurial intention [20]. Fayolle and Gailly (2015) through the perspective of entrepreneurial attitude research found that entrepreneurship education if the entrepreneurial attitude, by changing the potential entrepreneurs can promote the generation of the entrepreneurial spirit to encourage them to participate in the effect of entrepreneurship, most results of the empirical research of Chinese scholars also support this view, such as: $\mathrm{Du}$ J-J (2015) [21], Wang X-H etc. (2016) [22], Phan (2002) [23], through an empirical study of non-business students in Singapore, pointed out that the attitude towards education would influence the entrepreneurial intention of college students, because a large part of their attitude would be influenced by the entrepreneurial education they received in school [24]. Ozaralli and Rivenburgh (2016) conducted a comparative study on 589 junior students from an American university and a Turkish university, and the results showed that both American and Turkish students believed that entrepreneurship required more entrepreneurial training and education [25]. Giacomin et al. (2011) believe that people's entrepreneurial behavior actually increases with the increase of education [26]; Souitaris et al. (2007) conducted an experimental study on the entrepreneurial intention of science and engineering college students in Britain and France, and showed that entrepreneurial education courses and training have a positive impact on students' entrepreneurial intention. Students can get inspiration from entrepreneurial education and training, so that entrepre- 
neurial intention can be implemented in entrepreneurial practice [27]. Zhu H and Zhang Y-L (2014) obtained large sample data from 89 universities in Beijing, and based on the regression analysis from the perspective of student participation, they concluded that entrepreneurship education in universities can significantly improve the entrepreneurial intention of college students [28]. Although the research results of foreign scholars mostly show that entrepreneurship education has a positive impact on entrepreneurial intention, some research results have confirmed that entrepreneurship education has no impact or even a negative impact on entrepreneurial intention and its antecedents (Zhang X-E et al., 2016) [29]. Therefore, the influence of entrepreneurial education on entrepreneurial intention and entrepreneurial behavior is not always consistent and needs to be verified. Accordingly, we propose the following hypothesis:

H3: entrepreneurship education significantly positively affects the intention to start a business.

\subsection{Entrepreneurial Attitude and Entrepreneurial Intention}

The reason why entrepreneurial attitude is considered as one of the factors affecting entrepreneurial intention is that domestic and foreign scholars have confirmed that attitude is the most significant predictor of entrepreneurship and self-employment intention. For example, Ayalew and Zeleke (2018) took the senior engineering students from debraimarcos university, bayildar institute of technology and Gondar university in Ethiopia as samples, and found that entrepreneurial attitude did have a significant impact on students' intention to start their own businesses [18]. The research conclusion of Botsaris and Vamvaka (2016) shows that the entrepreneurial attitude dimension has a different influence on entrepreneurial intention, and the influence of emotional attitude on entrepreneurial intention is greater than that of instrumental attitude [8]. Nguyen (2017) studied the entrepreneurial intention of international business students in Vietnam. Exploratory factor analysis and multiple regression analysis were used to test the responses of 372 senior students. The research results confirmed that entrepreneurial attitude and perceived behavioral control were positively correlated with entrepreneurial intention [30]. In contrast, Zhang P et al. (2015) confirmed a surprising result that attitude failed to have a significant impact on entrepreneurial intention [31]. Based on this, this paper proposes the following hypothesis:

H4: entrepreneurial attitude can significantly and positively influence entrepreneurial intention.

This study draws on Ajzen's Theory of Planned Behavior (TPB) framework, and adds self-esteem variables to explore the influence of four independent variables of active personality, entrepreneurial education and entrepreneurial attitude on entrepreneurial intention. The theoretical model of this research is shown in Figure 1. 


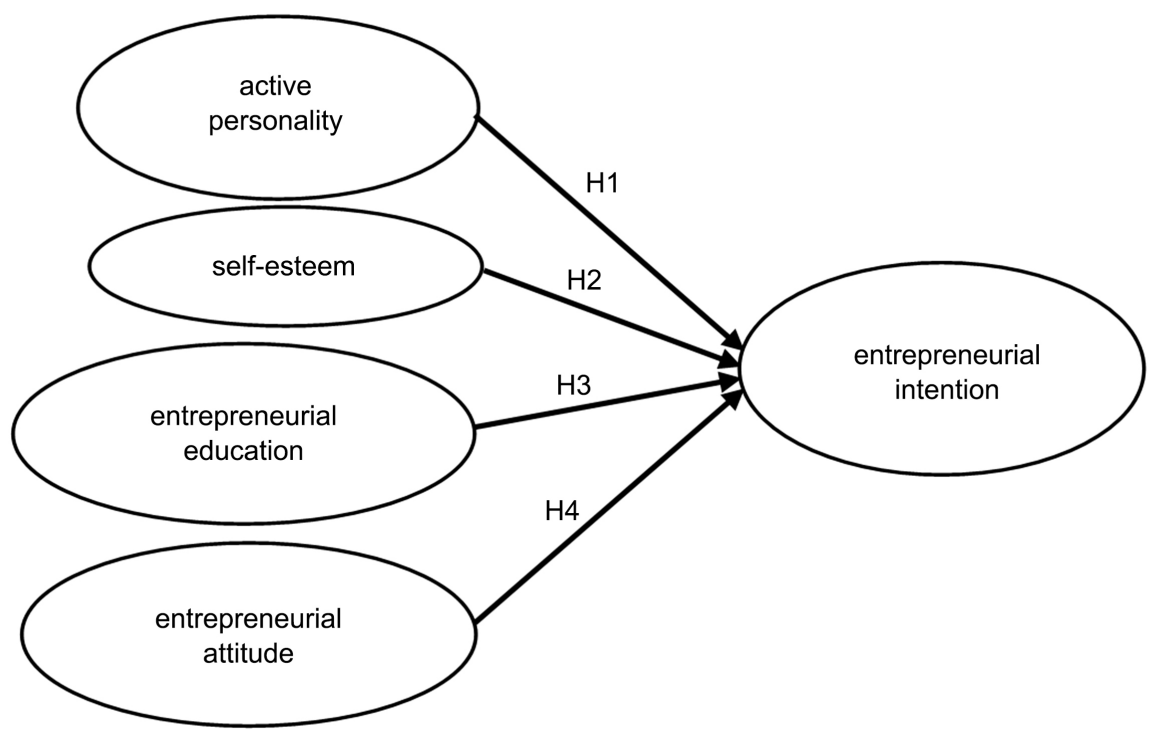

Figure 1. Theoretical model.

\section{Variable Measurement and Data Processing}

\subsection{Variable Measurement}

According to previous studies, demographic factors often include gender, age, personality, etc. In this study, the object is mainly college students, so the variables of grade are increased. Variables of social factors choose variables of family entrepreneurship background, because individuals exposed to entrepreneurial experience at an early stage will have an important impact on personal career choice [24].

The questionnaire consists of six parts, including background information, entrepreneurship education, self-esteem, proactive personality, entrepreneurial attitude and entrepreneurial intention, in which the entrepreneurial intention is the dependent variable, the background information is the control variable, and entrepreneurship education, self-esteem, proactive personality and entrepreneurial attitude are the independent variables.

\subsubsection{Background Information}

It mainly involves the measurement of variables such as gender, grade, personality and family entrepreneurial background. According to Jung's point of view, personality is divided into extroversion and introversion. The entry for the family business background measurement is "has any member of your family ever started (or is currently doing) a business or individual business?" The answer is yes or no.

\subsubsection{Proactive Personality}

The proactive personality was measured using 10 items in the articles of Bateman and Crant (1993). The responses were in the form of a 5-point Likert scale, with 1 representing strongly disagree and 5 representing strongly agree [16]. The variable was named PROA, and Cronbach's alpha was 0.895 . 


\subsubsection{Self-Esteem}

The most commonly used scale to measure personal self-esteem is adopted in the world. The scale was developed by American psychologist Rosenberg. It consists of 10 measuring questions to measure how good or bad a person feels about himself [32]. The responses were in the form of a 5-point Likert scale, with 1 representing strong disagreement and 5 indicating strong agreement. The variable name is defined as CONF.

\subsubsection{Entrepreneurship Education}

Entrepreneurship education can influence a person's entrepreneurial attitude and intention. The study by Phan et al. (2002) used 6 items to measure the respondents' attitudes towards entrepreneurship education. In order to analyze college students' attitudes towards entrepreneurship education in the domestic context, 6 items were bidirectional translated to ensure the accuracy of verbal expression [11]. The responses were in the form of a 5-point Likert scale, with 1 representing strong disagreement and 5 indicating strong agreement. The original author to six items together as a factor of 2, respectively defined as "attitudes towards entrepreneurship (including four entries, variable called ATTE, Cronbach's alpha 0.898)" and "attitude toward experience (including two entries, variable called ATTP, Cronbach's alpha 0.500 is less than 0.8 , due to the low reliability, eliminate) in the study of subsequent correlation analysis".

\subsubsection{Entrepreneurial Attitude}

According to the study of Phan et al. (2002), a total of 9 items were used to measure individuals' attitudes towards entrepreneurship. The response was in the form of a 5-point Likert scale, with 1 indicating strongly disagree and 5 indicating strongly agree [11]. The variable named ATTI, Cronbach's alpha was 0.950.

\subsubsection{Entrepreneurial Intention}

According to the measurement of entrepreneurial intention in Batsakis and Vamvaka (2016) articles, there are 10 items in total. The responses are in the form of a 5-point Likert scale, 1 stands for strongly disagree, 5 stands for strongly agree [15]. The variable was named INTEN, Cronbach's alpha was 0.968 .

\subsection{Data Collection and Processing}

\subsubsection{Sample Selection and Collection}

After the selected variables are designed for the questionnaire, the questionnaire is distributed through the questionnaire star platform. First, distribute and collect on a small scale. The time is from June 25th to July 5th, 2019. 280 valid questionnaires are collected. After exploratory factor analysis, the reliability and validity of the questionnaire are both good; then the large-scale survey, time from July 10th to October 9th, 2019, 388 valid questionnaires were recovered for confirmatory factor analysis; finally, after combining the two questionnaire data, a total of 668 valid questionnaires were recovered for correlation analysis and regression analysis. Table 1 shows the composition distribution of samples. 
Table 1. Composition distribution of samples.

\begin{tabular}{|c|c|c|c|}
\hline Classification & Indicators & Frequency & Frequency (\%) \\
\hline \multirow{3}{*}{ Gender } & male & 215 & 32.2 \\
\hline & & & \\
\hline & female & 453 & 67.8 \\
\hline \multirow{3}{*}{ Character } & extroverted & 315 & 47.2 \\
\hline & & & \\
\hline & introverts & 353 & 52.8 \\
\hline \multirow{2}{*}{$\begin{array}{l}\text { Family Business } \\
\text { Background }\end{array}$} & yes & 255 & 38.2 \\
\hline & no & 413 & 61.8 \\
\hline \multirow{5}{*}{ Grade } & freshman & 445 & 66.6 \\
\hline & sophomore & 26 & 3.9 \\
\hline & junior & 91 & 13.6 \\
\hline & senior & 78 & 11.7 \\
\hline & $\begin{array}{c}\text { graduated from the } \\
\text { university }\end{array}$ & 28 & 4.2 \\
\hline
\end{tabular}

\subsubsection{Reliability and Validity Test}

\section{1) Reliability Test}

Before exploratory factor analysis, it is usually necessary to judge whether it is suitable for exploratory factor analysis according to the significance of KMO value and Bartlett Spherical Inspection. In the previous empirical analysis of scholars, when Bartlett Spherical Inspection is significant, most of the factor analysis can only be performed if the KMO value is above 0.5 . At the same time, it is required that the factor load should be no less than 0.7. After the exploratory factor analysis of 280 samples collected from the first group using SPSS26.0 software, the index of factor load less than 0.7 is eliminated: 2 items of attitude towards the imparts of entrepreneurial experience, and proactive personality (items 3 and 6). When analyzed by SPSS dimension reduction factor, only one factor was obtained for entrepreneurial education, proactive personality, entrepreneurial attitude and entrepreneurial intention, respectively. Meanwhile, both $\mathrm{KMO}$ value and Cronbach's transparency reached above 0.8 , indicating good reliability and surface validity. Since the self-esteem variables are based on the scale of self-esteem recognized by the academic community, the relevant exploration and verification analysis will not be conducted in this paper [32]. The correlation analysis values of each variable are shown in Table 2 .

\section{2) Validity Test}

In the analysis, the reliability and validity of the scale interaction validation is often adopted by scholars, namely first using exploratory factor analysis (EFA) is a set of samples for analysis, in order to obtain scale possible factor structure, and then adopted confirmatory factor analysis (CFA) to validate another set of 
Table 2. Factor analysis $\mathrm{N}=280$.

\begin{tabular}{cccccc}
\hline Variable & $\begin{array}{c}\text { Number of } \\
\text { entries }\end{array}$ & $\begin{array}{c}\text { Minimum } \\
\text { factor load }\end{array}$ & $\begin{array}{c}\text { Cronbach's } \\
\text { alpha }\end{array}$ & KMO & $\begin{array}{c}\text { Total variance } \\
\text { interpretation }\end{array}$ \\
\hline Proactive personality & 8 & 0.709 & 0.895 & 0.893 & $59.406 \%$ \\
Entrepreneurship education & 4 & 0.826 & 0.898 & 0.814 & $77.596 \%$ \\
Entrepreneurial attitude & 9 & 0.803 & 0.950 & 0.915 & $70.465 \%$ \\
Entrepreneurial intention & 10 & 0.811 & 0.968 & 0.943 & $77.504 \%$ \\
\hline
\end{tabular}

Note: The data in the table is calculated by SPSS software.

samples and correct the above factor structure, further ensure the factor structure can finally get true scale. The SPSS software was used to conduct exploratory factor analysis on the scale, and the factor structure of the scale was preliminarily determined. In this part, another part of samples $(\mathrm{N}=388)$ will be used for confirmatory factor analysis to test the factor structure of the questionnaire on entrepreneurial education attitude, entrepreneurial attitude and entrepreneurial intention. The primary purpose of confirmatory factor analysis is to test the ability of a predefined factor model to fit the actual data.

Based on the sampling data of the second group $(\mathrm{N}=388)$, using AMOS24.0 software confirmatory factor analysis, the model fitting coefficient Table 3, can be seen from Table 3, are less than $3 \mathrm{CMIN} / \mathrm{DF}$, have very good fitting effect, RMSEA is less than 0.08, RMR is less than 0.05, GFI, NFI, CFI were greater than 0.9 , reached the requirements of confirmatory factor analysis, has good structure validity. As shown in Table 4, the combined reliability (CR) of each latent variable is very high, with a minimum of 0.901 , which is much higher than 0.6. In Table 4, AVE values are all higher than 0.5 , indicating that all latent variables have good convergent validity. Moreover, the square root of AVE is much higher than the correlation coefficient between the variable itself and other variables, indicating that the discriminant validity of each latent variable is relatively high.

\section{3) Correlation Analysis}

According to the above content, entrepreneurial intention will be influenced by variables such as entrepreneurial education, self-esteem, proactive personality and entrepreneurial attitude. These variables are first included in the relevant analysis, and the specific results are shown in Table 4. Among the control variables, gender and grade were negatively correlated with entrepreneurial intention $(\mathrm{r}=-0.163, \mathrm{p}<0.01 ; \mathrm{R}=-0.084, \mathrm{p}<0.05)$, and there was a positive correlation between personality and family entrepreneurial background and entrepreneurial intention ( $\mathrm{r}=0.140, \mathrm{p}<0.01 ; \mathrm{R}=0.125, \mathrm{p}<0.01$ ); Latent variables were positively correlated with entrepreneurial intention $(\mathrm{r}=0.432, \mathrm{p}<0.01) . \mathrm{R}=$ $0.152, \mathrm{p}<0.05, \mathrm{r}=0.534, \mathrm{p}<0.01 ; \mathrm{R}=0.356, \mathrm{p}<0.05)$. From the above results, it can be preliminarily concluded that the results of the correlation between variables and the above assumptions are reasonable to some extent, which lays a foundation for the next step of regression analysis. 
Table 3. Fitting coefficient table $\mathrm{N}=388$.

\begin{tabular}{ccccccc}
\hline & CMIN/DF & RMSEA & RMR & GFI & NFI & CFI \\
\hline Proactive personality & 2.921 & 0.070 & 0.021 & 0.971 & 0.975 & 0.984 \\
Entrepreneurship education & 0.787 & 0.000 & 0.005 & 0.999 & 0.999 & 1.000 \\
Entrepreneurial attitude & 2.118 & 0.054 & 0.009 & 0.985 & 0.992 & 0.996 \\
Entrepreneurial intention & 1.835 & 0.046 & 0.012 & 0.982 & 0.993 & 0.997 \\
\hline
\end{tabular}

Note: The data in the table is calculated by AMOS software.

Table 4. Correlation coefficient $\mathrm{N}=668$.

\begin{tabular}{|c|c|c|c|c|c|c|c|c|c|}
\hline & 1 & 2 & 3 & 4 & 5 & 6 & 7 & 8 & 9 \\
\hline Gender & 1 & & & & & & & & \\
\hline Grade & -0.017 & 1 & & & & & & & \\
\hline Character & 0.035 & 0.004 & 1 & & & & & & \\
\hline Family business background & 0.014 & -0.038 & $0.091^{*}$ & 1 & & & & & \\
\hline Entrepreneurship education & 0.042 & $0.116^{\star \star}$ & $0.087^{\star}$ & 0.07 & 0.834 & & & & \\
\hline self-esteem & 0.07 & -0.047 & $0.212^{\star *}$ & $0.110^{\star *}$ & $0.130^{* *}$ & 0.736 & & & \\
\hline Proactive personality & $-0.089^{*}$ & -0.043 & $0.179^{* *}$ & $0.138^{* *}$ & $0.433^{* *}$ & $0.392^{* *}$ & 0.780 & & \\
\hline Entrepreneurial attitude & 0.02 & 0.05 & $0.079^{*}$ & $0.088^{*}$ & $0.493^{* *}$ & $0.290^{* *}$ & $0.605^{* *}$ & 0.852 & \\
\hline Entrepreneurial intention & $-0.163^{\star *}$ & $-0.084^{\star}$ & $0.140^{\star *}$ & $0.125^{\star *}$ & $0.432^{* *}$ & $0.152^{* *}$ & $0.534^{* *}$ & $0.356^{\star *}$ & 0.799 \\
\hline AVE & & & & & 0.695 & 0.541 & 0.609 & 0.726 & 0.639 \\
\hline CR & & & & & 0.901 & 0.904 & 0.932 & 0.964 & 0.941 \\
\hline
\end{tabular}

Note: ${ }^{*}$ means $\mathrm{p}<0.01,{ }^{*}$ means $\mathrm{p}<0.05$; The diagonal is the square root of AVE.

\section{4) Regression Analysis}

The results on the basis of the above correlation analysis, the gender, grade, character and family business background as control variable, entrepreneurship education, self-esteem and personality, attitude of entrepreneurship, as the independent variables, entrepreneurial intention as the dependent variable regression analysis, the results as shown in Table 5 , the correlation coefficient of model $2, R^{2}=0.371$, adjust the $R$ square is $0.303, F$ value is 74.429 , significant is 0.000 , which shows better fit of the model, regression effect is significant.

As can be seen from model 1 in Table 5, the control variables including gender, grade, personality and family background have significant influence on entrepreneurial intention at the levels of $0.01,0.05,0.01$ and 0.01 , respectively. Gender and grade have a negative influence on entrepreneurial intention, indicating that male has a stronger entrepreneurial intention than female. Junior college students are more willing to start a business than senior college students 
Table 5. Regression model of entrepreneurial intention.

\begin{tabular}{ccc}
\hline Model & Model 1 & Model 2 \\
gender & $0.317^{* *}$ & $0.258^{* *}$ \\
grade & $0.057^{\star}$ & $0.069^{* *}$ \\
character & $0.236^{* *}$ & 0.096 \\
family business background & $0.200^{* *}$ & 0.088 \\
entrepreneurship education & & $0.275^{* *}$ \\
self-esteem & & 0.090 \\
proactive personality & & $0.575^{* *}$ \\
entrepreneurial attitude & & 0.020 \\
$\mathrm{R}^{2}$ & 0.068 & 0.371 \\
$\Delta \mathrm{R}^{2}$ & 0.068 & 0.303 \\
$\mathrm{~F}$ & $12.069^{* *}$ & $74.429^{* *}$
\end{tabular}

Note: ${ }^{*}$ means $\mathrm{p}<0.01,{ }^{\star}$ means $\mathrm{p}<0.05$.

or even graduates, which is basically consistent with the research conclusions of domestic scholars. College students' personality and family background both have a positive and significant influence on entrepreneurial intention at the level of 0.01 , indicating that college students with extroverted personality are more willing to choose entrepreneurship than introverted ones, and college students with family entrepreneurial background are more inclined to choose entrepreneurship than college students without entrepreneurial background.

From model 2, it can be seen that the regression coefficients of entrepreneurial education variables (personal equity $=0.275, \mathrm{p}=0.000<0.01$ ) and proactive personality variables (personal equity $=0.275, \mathrm{p}=0.000<0.01$ ) are both positive and the significance level is lower than 0.01 , indicating that both of them have a positive and significant impact on entrepreneurial intention. Hypothesis $\mathrm{H} 1$ and H3 were verified. The regression coefficients of self-respect $(=-0.090, \mathrm{p}=$ $0.130>0.05)$ and entrepreneurial attitude $(=-0.20, \mathrm{p}=0.712>0.05)$ were all negative, and the significance level was higher than 0.05 , indicating that they did not reach the level that significantly affected the entrepreneurial intention. Hypothesis $\mathrm{H} 2$ and $\mathrm{H} 4$ were not verified.

\section{Discussion}

This paper is devoted to the analysis and research of factors affecting entrepreneurial intention. Through the verification and regression analysis of the survey data of 668 people, the following results are drawn:

1) The control variables selected in this paper, such as gender and grade, significantly affect the generation of entrepreneurial intention. Among them, gender 
has a significant negative influence on the entrepreneurial intention, indicating that the entrepreneurial intention of men is higher than that of women, which is consistent with the previous research conclusions, such as: Wang $\mathrm{X}-\mathrm{H}$ et al. (2016) [23], Wang B and Feng Z-J (2017) [33]. China's social and cultural factors (poor children, rich daughters, marry and settle down, etc.) put more pressure on men than women, and men's work view is also greatly influenced. The social cognition that starting a business as a boss brings more wealth than the temptation of going to work also makes men tend to choose starting a business. The negative influence of grade on entrepreneurial intention was significant, indicating that the higher the grade, the lower the entrepreneurial intention. As college students learn more about entrepreneurship, they will become more aware of risks and realize that failure in entrepreneurship is sometimes inevitable, thus reducing their intention to start a business. Neither extroversion nor introversion significantly affected entrepreneurial intention. Family entrepreneurial background has no significant influence on entrepreneurial intention, indicating that families with entrepreneurial experience have no positive influence on individuals' entrepreneurial intention. This is inconsistent with the research conclusions of foreign scholars such as Carr and Sequeira (2007) [34], Phan et al. (2002) [24]. It is generally believed that the family has an objective influence on the attitude and behavior of individuals, and entrepreneurial families may be motivated to start their own businesses due to their entrepreneurial financial support, social network and encouragement from family members. However, this study has not been verified, and there must be other reasons for this, which are worth considering.

2) Through regression analysis, the effect of the two independent variables of entrepreneurial education and proactive personality was verified, which is consistent with the previous research conclusions. This conclusion indicates that modern entrepreneurial education has a huge potential impact on the cultivation of more entrepreneurs in the future. Second, it shows that proactive personality, as one of the individual characteristics, has a great promoting effect on the individual's entrepreneurial intention. The variable of self-esteem has no significant influence on entrepreneurial intention, which is inconsistent with the research results of Obschonka et al. (2016) [7], which may also be caused by the inconsistency between China's environment and that of Finland. Entrepreneurial attitude variable has no significant influence on entrepreneurial intention, which is different from the conclusion that attitude can influence intention in the theory of planned behavior. When entrepreneurial education, proactive personality and control variables are included, the attitude variable obviously has no effect, and it is worth noting that it also shows a negative correlation. This conclusion, on the one hand, affirming the role of entrepreneurial education and proactive personality, also explains that attitude and intention are not consistent, and describes the obvious deviation between people's attitude to talk about something and their real intention to do it. 


\section{Conclusions}

In this study, questionnaire design was firstly conducted through literature review and relevant data were collected through online platform. Secondly, SPSS26.0 and AMOS24.0 are used to explore and verify the validity and reliability of the corresponding variables. Third, correlation analysis and regression analysis were carried out with SPSS to verify the correlation hypothesis.

Through analysis, we got the following two conclusions:

1) In the control variables, gender and grade both significantly affect entrepreneurial intention, while personality and family background did not significantly affect entrepreneurial intention;

2) In independent variables, entrepreneurial education and proactive personality both significantly affected entrepreneurial intention, while self-esteem and entrepreneurial attitude did not significantly affect entrepreneurial intention.

\section{Acknowledgements}

The authors greatly thank Dr. Chen for kindly providing early generation seed of the article. Special thanks Entrepreneurship Ecosystem Research Center for its cooperation and support in this research, including questionnaire design, distribution and financial support.

\section{Funding}

This study was funded by industry university research collaborative project of Ministry of Education of the PRC (201901053002), Research on the path of Cultivating College Students' entrepreneurial ability under the background of "new economic management" of Anhui University of Finance and Economics (ACJYYB2019100).

\section{Conflicts of Interest}

The authors declare no conflicts of interest regarding the publication of this paper.

\section{References}

[1] Drucker, P. (1985) Innovation and Entrepreneurship: Practices and Principles. Harper \& Row, New York.

[2] Shane, S. and Venkataraman, S. (2000) The Promise of Entrepreneurship as a Field of Research. Academy of Management Review, 25, 217-226. https://doi.org/10.5465/amr.2000.2791611

[3] Cai, Y. and Zhao, N. (2014) Analysis of College Students' Entrepreneurial Intention Based on Principal Component Regression Method. Higher Education Exploration, 4, 160-165.

[4] Qian, Y.-H. (2007) Research on the Influencing Factors of Entrepreneurial Intention. Journal of Zhejiang University (Humanities and Social Sciences Edition), 37, 144-152.

[5] Li, Y.-Q., Bai, X.-X., Mao, Y. and Zeng, Z. (2008) A Review of the Factors Influen- 
cing Entrepreneurial Intention. Economic Dynamics, 2, 81-83.

[6] Ji, X.-Y. and Liu, A.-J. (2016) Research on the Influencing Factors of College Students' Entrepreneurial Intention. Higher Education Exploration, 9, 113-120, 128.

[7] Obschonka, M., Hakkarainen, K., Lonka, K., et al. (2017) Entrepreneurship as a Twenty-First Century Skill: Entrepreneurial Alertness and Intention in the Transition to Adulthood. Small Business Economics, 48, 487-501. https://doi.org/10.1007/s11187-016-9798-6

[8] Botsaris, C. and Vamvaka, V. (2016) Attitude toward Entrepreneurship: Structure, Prediction from Behavioral Beliefs, and Relation to Entrepreneurial Intention. Journal of the Knowledge Economy, 2, 433-460. https://doi.org/10.1007/s13132-014-0227-2

[9] Bird, B. (1988) Implementing Entrepreneurial Ideas: The Case for Intention. Academy of Management Review, 13, 442-453. https://doi.org/10.5465/amr.1988.4306970

[10] Fan, W. and Wang, C.-M. (2006) A Confirmatory Factor Analysis of the Dimensional Structure of Entrepreneurial Intentions. Ergonomics, 12, 14-16.

[11] Bateman, T.-S. and Crant, J.-M. (1993) The Proactive Component of Organizational behaviors: A Measure and Correlates. Journal of Organizational Behaviors, 14, 103-118. https://doi.org/10.1002/job.4030140202

[12] Crant, J.-M. (1996) The Proactive Personality Scale as a Predictor of Entrepreneurial Intentions. Journal of Small Business Management, 34, 42-49.

[13] Crant, J.-M. (2000) The Proactive Personality Scale in Organizations. Journal of Management, 80, 435-462. https://doi.org/10.1177/014920630002600304

[14] Paul, J. and Shrivatava, A. (2016) Do Young Managers in a Developing Country Have Stronger Entrepreneurial Intentions? Theory and Debate. International Business Review, 25, 1197-1210. https://doi.org/10.1016/j.ibusrev.2016.03.003

[15] Jane, D.-D., Duan, J.-Y. and Zhu, Y.-L. (2010) Conception Measurement, Influencing Factors and Theoretical Model of Entrepreneurial Intention. Advances in Psychological Science, 18, 162-169.

[16] Chen, M.-J. (2009) Research on the Relationship between Proactive Personality and Entrepreneurial Intention of College Students. Master's Thesis, Jinan University, Guangzhou.

[17] Ismail, N., Jaffar, N. and Hooi, T.S. (2013) Using EAO Model to Predict the SelfEmployment Intentions among the Universities Undergraduates in Malaysia. International Journal of Trade, Economics and Finance, 4, 90-97. https://doi.org/10.7763/IJTEF.2013.V4.302

[18] Ayalew, M.-M. and Zeleke, S.-A. (2018) Modeling the Impact of Entrepreneurial Attitude on Self-Employment Intention among Engineering Students in Ethiopia. Journal of Innovation and Entrepreneurship, 7, 8-35. https://doi.org/10.1186/s13731-018-0088-1

[19] Walter, S., Parboteeah, K.-P. and Walter, A. (2013) University Departments and Self-Employment Intentions of Business Students: A Cross-Level Analysis. Entrepreneurship Theory \& Practice, 37, 175-200. https://doi.org/10.1111/j.1540-6520.2011.00460.x

[20] Oosterbeek, H., Praag, M.-V. and Ijsselstein, A. (2010) The Impact of Entrepreneurship Education on Entrepreneurship Skills and Motivation. European Economic Review, 54, 442-454. https://doi.org/10.1016/j.euroecorev.2009.08.002

[21] Fayolle, A. and Gailly, B. (2015) The Impact of Entrepreneurship Education on Entrepreneurial Attitudes and Intention: Hysteresis and Persistence. Journal of Small 
Business Management, 53, 75-93. https://doi.org/10.1111/jsbm.12065

[22] Du, J.-J. and Wang, J.-J. (2015) An Empirical Study on the Impact of Entrepreneurship Education on College Students' Entrepreneurial Intention. College Education Management, 9, 113-119.

[23] Wang, X.-H., Bo, F.-Y. and Lei, J.-S. (2016) Entrepreneurship Education Research, the Influence on College Students' Entrepreneurial Intention and Comparisons of Higher Vocational Students and Undergraduate Students. Journal of Tsinghua University Education Research, 5, 116-124.

[24] Phan, P.-H., Wong, P.-K. and Wang, C.-K. (2002) Antecedents to Entrepreneurship among University Students in Singapore: Beliefs, Attitudes and Background. Journal of Enterprising Culture, 10, 151-174.

https://doi.org/10.1142/S0218495802000189

[25] Ozaralli, N. and Rivenburgh, N.-K. (2016) Entrepreneurial Intention: Antecedents to Entrepreneurial Behavior in the U.S.A. and Turkey. Journal of Global Entrepreneurship Research, 6, 3-34. https://doi.org/10.1186/s40497-016-0047-x

[26] Giacomin, O., Janssen, F., Pruett, M., Shinnar, S., Llopis, F. and Toney, B. (2011) Entrepreneurial Intentions, Motivations and Barriers: Differences among American, Asian and European Students. International Entrepreneurship and Management Journal, 7, 219-238. https://doi.org/10.1007/s11365-010-0155-y

[27] Souitaris, V., Zerbinati, S. and Al-laham, A. (2007) Do Entrepreneurship Programs Raise Entrepreneurial Intention of Science and Engineering Students? The Effect of Learning, Inspiration and Resources. Journal of Business Venturing, 22, 566-591. https://doi.org/10.1016/j.jbusvent.2006.05.002

[28] Zhu, H. and Zhang, Y.-L. (2014) The Influence Mechanism of Entrepreneurship Education in Beijing Universities on the Entrepreneurial Intention of Junior College Students-An Empirical Analysis Based on the Perspective of Student Participation. Tsinghua University Education Research, 35, 100-107.

[29] Zhang, X.-E. and Zhang, K. (2016) Review and Prospect of the Research on the Mechanism of Entrepreneurial Education on Entrepreneurial Intention. Foreign Economy and Management, 38, 104-112.

[30] Nguyen, C. (2017) Entrepreneurial Intention of International Business Students in Vietnam: A Survey of the Country Joining the Trans-Pacific. Journal of Innovation and Entrepreneurship, 6, 1-13. https://doi.org/10.1186/s13731-017-0066-Z

[31] Zhang, P., Wang, D.-D. and Owen, C.-L. (2015) A Study of Entrepreneurial Intention of University Students. Entrepreneurship Research Journal, 5, 61-82. https://doi.org/10.1515/erj-2014-0004

[32] Rosenberg, M. (1965) Society and the Adolescent Self-Image. Princeton University Press, Princeton. https://doi.org/10.1515/9781400876136

[33] Wang, B. and Feng, Z.-J. (2017) Entrepreneurial Intention of College Graduates and Entrepreneurship Education in Schools. Higher Education Forum, 12, 113-115.

[34] Carr, J.-C. and Sequeira, J.-M. (2007) Prior Family Business Exposure as Intergenerational Influence and Entrepreneurial Intent: A Theory of Planned Behavior Approach. Journal of Business Research, 60, 1090-1098. https://doi.org/10.1016/j.jbusres.2006.12.016 